or three days. As the patient's deafness-due, as I discovered, to an exostosis-eontinued to, increase, he was brought to me by Mr. Chaldecott, of Dorking, with whose assistance, on September 21st, I operated with the dental engine. The systematic cleansing of the meatus and the repeated application of a solution of carbolic acid constituted the main after-treatment, and the patient is now steadily regaining his hearing.

CAsE XX - - H. C., a gentleman aged 61, was sent to me by Dr. Lawrence, of Chepstow. Three or four years previous to his first visit to me, in 1886, he had twice suffered from deafness of the right ear, consequent, apparently, on abscess caused by the ingress of water into the meatus. After a slight discharge for a fortnight; the deafness hau on both occasions entirely ceased. In August, 1886, subsequent to bathing every other day or so during four weeks at Whitby, deafness came on in the left ear, lasting a month. The patient, who, when he came to me, was very deaf in both ears, and suffered from considerable pain in the right side of the head, presented an exostosis on the posterior wall of each external meatus. On October 20th, 1886, I drilled through both by means of the dental engine. No pain or injury to the general health ensued, and hearing was restored some five weeks from that date to the left ear, and a few days later to the right. On January 6th, 1887, he wrote as follows: "I am very happy to be able to tell you that I am as nearly as possible cured of my deafness. When I come to town I will certainly give you a call, that you may see how successful your operation has been."

CASE XXr. - Emma H., a hospital patient, came to me November 3rd, 1886, with an exostosis of the left ear, the size of a large pea, and completely closing the external auditory meatus, to the anterior wall of which it was attached by a small pedicle. The development of the growth had begun with shooting pains in the ear two years previously, and deatness had gradually increased, until it had now become almost absolute. In this case the use of strong forceps sufficed for the ready removal of the whole of the exostosis.

CASE XXII. $-\mathrm{K}$. W., aged 34, formerly a nurse, was admitted into the Manvers Ward, St. Mary's Hospital, November 10th, 1886, on account of an ill-defined swelling below the left ear, corresponding, in position with the parotid gland, together with typical facial paralysis. The patient, though unhealthy-looking, was fairly well nourished. Her family history was on the whole good, but she had lost her mother from softening of the brain, and a brother had occasional attacks of paralysis. Except for sick headache, at one time her general condition may be said to have been quite satisfactory. Ophthalmic examination showed white streaks upon the retina; by urinary tests, however, no albuminuria could be detected.

Five years previous to admission into hospital; she began to suffer pain behind the left ear; and three years later she noticed in that situation a hard, somewhat tender swelling. This slowly increased in size; and occasionally there was a slight viscid and rather offensive discharge from the ear. The facial paralysis commenced soon after the swelling became spparent. The pain behind the ear, for which opiated fomentations have been used, was described as of a stabbing character, and as suning in a line from the ear to the throat.

By November 20th, the patient's face had become much swollen, and she had endured several attacks of megrim with vomiting. She was seen by me on the 25 th, when I discovered in the left meatus, attached by a broad base to its posterior wall, and all but completely occluding its cavity, a large exostosis, which on percussion with a probe gave a clear ringing sound, as though it were composed of hard bone. The application of forceps proved the growth to be of loose construction, so that nnmerous small pieces of it, together with some granulation-tissue, were easily removed, and a passage thraugh the meatus was secured. The following week the passage was enlarged with the dental drill sufficiently to allow of a free discharge of pus, the pain in the head being thereby much relieved.

CASE XXIII. - The following case is one of a class in which immediate removal of an exostosis is not to be advised. E. L., a girl of 14 came to me at St. Mary's Hospital, October 24th, 1886. She had from babyhood suffered from otorrhœa. On November 12th, after removal, under chloroform, of a polypus in the right meatus, I found on its upper wall, and quite close to the drumbead, a large bony outgrowth. As the meatus is not yet (and may never be) occluded, the position of the growth certainly for the present contra-indicates operative interference.

CASE XXIv.-Major R. B., sent by Dr. Smith, of Newport, to consult me, November 23rd, 1886, gives the following history of his case. After three years' service with his regiment in Burmah, he contracted endemic fever, and was invalided home in 1867. On recovery, he discovered himself to be persistently deaf in the left ear, insomuch that a watch held to $i i$ was scarcely audible. He remarked his deaf- ness most in a noise, and particularly in that caused by driving, railway travelling, or the conversation, as at a dinner-party, of severel persons together. Near the close of 1884, he learnt from his local medical attendant that he had an unnatural growth in each ear; as, hawever, his deafness was not worse than usual, he attached no weight to this piece of information. In September, 1886, however, after \& day's shooting, he experienced complete deafness in the right ear; this left him as suddenly as it had come on, but only to return six weeks latex. By the advice of his medical man, whom he now again consulted, he saw me on November 23rd. Finding him to be the subject of : double exostosis, I recommended operation by drilling. This I performed on December 6th. The patient did well, keeping his bed for only a short time, and suffering but slightly. He retarned home on December 18th, twelve days after the operation, able to resume his, usual occupations. The hearing of the right ear is now completely restored; that of the left, which was regained in fair measure for a few days, we may hope to be permanently restored, as in other cases, on the removal of the gramulations blocking the meatus. $\mathrm{He}$ says he "now hears as well as he did twenty years ago."

CASE XXV. -Mr. E. L. P., aged 27, was sent by Dr. Thursfield to consult me, December 7th, 1886. He first noticed a growth in his left ear about July, 1881, but thinks he must have been deaf for some time before then. By the advice of his medical attendant he visited an aurist, who diagnosed an exostosis, and by syringing dislodged from behind it a piece of wax about as large as a good-sized pea. Being recommended not to undergo an operation unless increase in the bulk of the tumour became perceptible, the patient, though often very deaf, troubled himself no further respecting his condition until near the end of November, 1886. He then, while washing, began to suffer from persistent pain in his ear. Dr. Thursfield, whom he consulted shortly afterwards, suggested he should see me without delay. On December 9 th the drilling of the tumour was successfully effected, the operation lasting forty minutes. The patient made an excellent recovery, and on January $3 \mathrm{rd}$, 1887, he felt perfectly well ; all discharge had ceased, and a watch was audible at 12 inches from the ear.

\section{THORACIC ANEURYSM.}

BY C. W. SUCKLING, M.D.LoNd., M.R.C.P., Physician to the Queen's Hospital, Birmingham.

DuRING the past two years, I have had under my careat the Workhouse Infirmary and at the Queen's Hospital altogether twenty cases of thoracic aneurysm. A brief summary of the chief symptoms met with in these cases may be of interest.

Of the twenty cases, three were women, seventeen men; none of the patients were under 30 years of age.

Between 30 and 40 years there were 8 cases

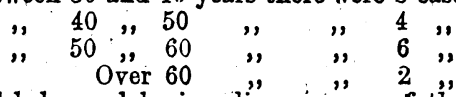

All of them had led very laborious lives; seven of the men had been porters, and had been accustomed to carry heavy weights. A history of syphilis was obtained in four cases only, and dated back sereral years in each. There was a history of syphilis in one of the women; in the other two, heavy work seemed to have been the cause. In only three cases could a history of sudden onset of symptoms be obtained. In one man, pain in the chest came on immediately after being crushed, at a political meeting. In another, pain was felt after lifting a sack of flour. In the third case, pain in the chest supervened immediately after ligature of the external iliac artery for femoral aneurysm.

Of all the symptoms, pain was the most constantly present. Pain was complained of in eighteen of the twenty cases. When present, it was always felt behind the upper portion of the sternum, occasionally down both arms, more frequently down the left alone. The pain varied much in intensity, and was always re. lieved by rest and by iodide of potassium. Dyspncea was a prominent symptom in eight of the cases, in some occasional, in others constant, but with exacerbations. Stridor on inspiration and expiration was marked in five cases; this is, of course, a symptom that should at once lead to a careful examination of the chest for aneurysm, yet it is frequently put down to asthma or bronchitis. Inequality in the radial pulses, dysphagia, hoarseness, brassy cough, and inequality in the pupils were frequently present. Sphygmographic tracings were taken in most of the cases, and one of the few purposes for which the sphygmograph is useful is the localisation of thoracic aneurysm. In a case of innominate aneurysm, in which dyspnce was an urgent 
symptom, there were well marked reypiratory undalations in the pulse tracing of the right radial artery.

The destructive pnenmonia which follows presenre on the bronchus was observed in six of the twenty cases. This destructive pneumonia may be mistaken for malignant disease of the lung, or for ordinary phthisis.

In one necropsy an aneurysm, involving the extra-pericardiac portion of the ascending aorta, had compressed the right bronchus, and had led to consolidation of the upper lobe of the right lang. During life the patient, a woman, had suffered from hremoptysis, slight stridor and exhanstion, with marked codems of the head, nock, and upper extremities. There was dulness over the nanubrium, and the usual signs of consolidation of a considerable portion of the right lung. There was no pulsation to be seen or felt, and no pain had ever been experienced; in addition, there was no fever during the time she was under observation. The balance of evidence was thought to be in favour of malignant growth, but at the necropsy an enormous aneurysm, with very thick walls, was found. It is well to remember that aneurysm is far more common than malignant growth in the mediastinum or of the lung. I have met with two cases of primary sarcoma of the lung during the time in which I have met with twenty cases of thoracic aneurysm.

This pneumonia is a very impor tant pressure-symptom; it may affect either the upper or lower lobe of the lung, and helps to localise a thoracic aneurysm, as in the following case. A man with an aneurysm of the femoral artery was operated on by Mr. Bennett May, the external iliac vessel being tied. He complained immediately after of pain in his chest, and a few months later presented signs of phthisis at the left apex. The consolidation of the left lung advanced; but, unlike what is usually seen in ordinary phthisis, the right lung was healthy, while the left was extensively consolidated. The aneurysm was supposed to be situated in the descending portion of the arch of the aorta, and to be growing forwards and compreesing the left bronchus, and this was found to be its exact position at the post-morlem examination.

In malignant disease the profound exhaustion which rapidly supervenes is very characteristic ; in addition, there is little if any fever, while in the consolidation resulting from pressure on the bronchus an irregular pyrexia is almost invariably present. In one case malig. nant disease of the upper lobe of the left lung was diagnosed; a day or two later a systolic bruit was heard in the interscapular region close to the spine. This threw a little doubt upon the diagnosis. Was the bruit due to pressure on the 2orts by the growth; or was there an aneurysm compressing the left bronchus and leading to a con. solidation of the left upper lobe? The absence of fever and the very marked exhaustion supported the diagnosis of malignant growth which was found to be present at the post-mortem examination. In four cases aortic regurgitation was present in addition to the aneurysm, probably being brought about by the same cause. In one case a donble Eruit was present at the base of the heart, with capillary pulsation but it was found after death that the aortic valves were perfectly competent, so that a diseased aorta alone can produce these conditions. In this case, also, the heart was not enlarged, only being displaced ; it seems that aneurysm, unless complicated with insufficiency of the aortic valves, does not lead to cardiac hypertrophy. A systolic bruit was heard in thirteen of the cases, in three no murmur at all. In two cases embolic phenomena were present, in both a left hemiplegia. In one case there was, in addition, embolism of the central artory of the retina on the same side, leaving well-marked atrophy of the disc. Nineteen of the twenty cases were aneurysms of the arch of the aorts outside the pericardium; one was innominate.

I have met with one case of acute aneurysmal dilatation of the intrapericardial portion of the aorta cansing death by perforation and hamorrhage into the pericardium. This was in a case of nlcerative endocarditis. The aneurysm was not diagnosed during life. In five cases the diagnosis could be made by inspection and palpation of the chest wall, there being evident bulging and pulsation; in fifteen there was neither of these symptoms. In nineteen of the twenty cases there was dulness on percussion over the manubrium or at the side of this portion of the sternum, attention being directed to this region by the patients' complaint of pain there. This region of the chest is often overlooked. It is a good rule to percuss the sternum in every case of chest-pain in men.

There is no such thing as mediastinal dulness in the healthy state, the note of the sternum in health being resonant, although there is no lung behind the first portion of it. Dulness over the manubrinm sterni is pathological, and means in the majority of cases mediastinal tumour, aneurysm being by far the commonest form. Tufnell's plan of treatment, together with the administration of iodide of potassium, gave great roliof in twelve cases. In two caces under this treatment the duinees almost diseppeared, the proesure symptoms complotoly so, and the diagnosis of aneurysm could not have been made withont a knowledge of the previous condition. The iodide was given in large doees, commoncing with ton grains, and increasing to a dose of a drachm or more, eccording to the tolerance and effects. In two or three cases the iodide 800 med to do harm, the pulse becoming very quick. Aconite in these cases suited bettor. Electrolysis was per. formed in one case with temporary relief.

\section{ANTIPYRIN IN SUNSTROKE.}

Bर Surazos G. A. HARRIS, M.R.C.S.E., L.R.C.P.Lond., B.M.S., Civil Burgeon, Simla.

THe following notos of a case of the hyperpyrexial form of insclation, which came under my observation at the Calcutta General Hospital, and which was in part treated with antipyrin, is of some interest. I believe it was one of the first, if not the first, case of insolation in which antipyrin was used to reduce the high temperature; at least, I have not seen any record of a previous case, though I know subsequent observations in tho United States of America were recorded in which antipyrin was used successfully to combat the hyperpyrexis of sunstroke. I regret that my own subsequent experi. ence did not confirm the hopes raised by the successful issue of the present case; but I think this was in part due to the doses being too small.

W. S., an American seaman, aged 40, was brought to the General Hospital, Calcutta, very shortly after 11 A.M., on May 19th, 1885. When admitted he was perfectly unconscious, and the only history obtainable was that ho had been seen early that day visiting several ships lying in port, and was known to have been drinking freely on several of these ships. Shortly before he was brought to the hospita\}, he had been found lying insensible on the Strand Road, which runs parallel with the River Hooghly.

On admission the temperature was $108^{\circ} \mathrm{F}$., at $11.15 \mathrm{~A}$.M., in the month and rectum. The patient was perfectly unconscious, with labonred and stertorous breathing; his face was markedly cyanotic; the akin of the whole surface was harsh, dry, and burning hot; the eyes were red and suffused, and both pupils contracted to a pin's point; there was a sweetish, sickly odour about the breath; the pulse was full and bounding; he was constantly throwing his arms about and groaning. There were a few superficial wounds on the scalp, filled with mud and gravel, and probably caused by falling on the ground when he first became insensible. Shortly after admission he vomited some undigested food and bilious-looking fluid, which smelt strongly of alcohol.

The patient's clothes being removed, he was at once well douched with cold water, given a large enems of iced water, then pat into a cold bath, and 10 grains of the neutral sulphate of quinine injected into his arm. Whilst in the bath his bowels acted freely. He was kept in the bath about ten minutes, ice being applied to the shaven head, and, before he was taken out, a drop of croton-oil was put on the back of his tongue. After the cold douche and the enems, the tempers. ture fell to $165^{\circ}$, and in the bath and after removal it kept on falling until 2.30 P.4., by which time it had fallen to 101\%. The cold bath had not boen repeated, but a largo sheet which was kept con. stantly wet with cold water was wrapped round him, and evaporation encouraged by constant fanning. Ice had been constantly applied to the hesd, but he had in no way regained conscionsness. Small quantities of Brand's essence vere put between his lips, but very little was swallowed. The convulsive twitching of the arms and legs was incessant, and there was the profoundest insensibility. The con. junctivæ and cornex conld be freely touched, and shouting into his ears produced no response. The pulse was 128, and of a running character ; the breathing continned stertorons. On any attempt being made to flex or extend the limbs they showed marked muscular rigidity with resistance. At 3.30 P.M. the temperature was $103.5^{\circ}$, and was apparently rising, notwithstanding the constant application of cold to the surface, so I determined to give antipyrin a trial, and 20 grains were dissolved in water and injected subcutaneously, and at 5 P.M. I repested this measure. In spite of this, the tempersture continued to rise, and at 5.45 P.M. Was $106^{\circ}$ in the rectum. At 6.10 P.M. the temperature was still $106^{\circ}$ in the rectum, and 30 grains of antipyrin were given by the mouth, and by 6.30 P.M. - that is, in twenty minutes - the temperature had fallen from $106^{\circ}$ to $102^{\circ}$. At 7.10 P.M. the 30-grain dose of antipyrin was repeated by the mouth; at 8.10 P.M. 15 grains were given by the mouth, and repeated at 9 P.M. and at 11 P.M. Subsequent to these big doses, the temperature did not 